\title{
GENÉTICA E MORAL: A MORAL DA HISTÓRIA
}

\author{
GENETICS AND MORALS: THE MORALS OF HISTORY
}

\author{
Psican. Norberto Carlos Irusta*
}

\section{INTRODUÇ̃̃̃O}

O avanço meteórico das biociências e o concomitante desenvolvimento da biotecnologia, a genética e o passo dado pelo projeto genoma humano (P.G.H.) e similares concorrentes, com sua previsível redefinição do vivente, as inevitáveis confusões entre a redefinição do vivente e uma redefinição do SER, as consequências dessas descobertas nas novas tecnologias de procriação e os seus efeitos sobre a relação do corpo, da imagem deste e de seu estar em relação no mundo e, entre tantos outros, o reposicionamento da subjetividade como modo de "conceber" o homem e como vivência existencial na singularidade dos indivíduos, constituem uma longa lista de questões que suscitam um amplo espectro de expectativas, por um lado, e profundas inquietações éticas e preocupações morais, por outro.

Bem alheios a essas preocupações, os cientistas hoje, como outrora os alquimistas, continuam afanosos à procura da "pedra filosofal" ou o Objeto causa de todas as coisas, como próprio de nossos dias, poderosos interesses econômicos os subsidiam e acicateiam numa verdadeira corrida pós-moderna pelo ouro e sua apropriação ${ }^{1}$.

* Norberto Carlos Irusta, faleceu repentinamente no dia 28 de junho de 2001, deixando manuscritos os originais deste texto sobre sua escrivaninha. 0 manuscrito foi digitado mantendo o conteúdo na integra: foram apenas completadas as notas de referência. $\mathrm{O}$ autor não fez a revisão final. Não temos certeza se sua última frase foi escrita. Cleila Elvira Lyra. Para esta edição, procedeu-se à atualização ortográfica.

Norberto Carlos Irusta suddenly died on June, $28^{\text {th }}, 2001$ and left some original manuscripts on his desk. This manuscript was typed keeping the integrity of its content and just reference notes were complemented in the originals. The author did not do a final review and we are not sure if the last sentence was written by him. Cleira Elvira Lyra. To this edition we did its orthographic actualization.

1 Tendo consumido bilhões de dólares na sua execução e abrindo perspectivas incalculáveis em termos econômicos, o projeto Genoma Humano viu o brilho do seu lançamento enbaçado pelas declarações do seu líder John Sulston, que não hesitou em chamar de "criminoso" ao seu concorrente em função de sua política de acesso aos dados genéticos. Fonte: Ciência on-line - das agencias internacionais do "the New York Times" - Folha On-line 12.02 .2001 
Filósofos, filósofos de direita, juristas, psicanalistas, sociólogos e outros auscultadores do sujeito e do sujeito em relação, debruçamo-nos hoje sobre os primeiros respingos não equacionados dessa complexa álgebra, tentando dimensionar os efeitos colaterais deste novo elixir, miraculoso que irá "aliviar o sofrimento da miséria humana".

As experiências recentes de seleção e higiene social, eugenia, eutanásia, controle de natalidade, manipulação de alimentos pela engenharia genética, práticas licitas e práticas espúrias geradas pelas condições atuais de "fabricação", transplante ou utilização de órgãos animais, somados ao sofisticado arsenal atual da biologia molecular e a propagandização antecipatória das possíveis, quase ilimitadas, produções realizáveis no campo da experiência genética, alavancadas pela aceleração que propiciavam sua instalação no ambiente ultradesenvolvido do cybermundo, acirram o debate histórico entre a ética e os avanços científicos no marco de uma suposta contradição inerente a eles. "Que restrições deveriam ser impostas às atividades dos que investigam a genética humana, se é que devem sofrer alguma restrição?" se questiona o físico Tom Wilkie autor do livro "Projeto Genoma Humano - um conhecimento perigoso". (WILKIE, 1994, p.25)

O Parlamento europeu adotou um relatório limitado dos trabalhos do Projeto Genoma, já desde 1989 - data destacável, pois demostra o pouco efeito produzido. O Conselho de Ministros da Comunidade Europeia instituiu um comitê de ética para supervisionar as implicações da nova biologia, e o Conselho da Europa articula uma convenção para proteção da pessoa humana com relação à ciência biomédica, entre tantas outras organizações privadas, governamentais, não governamentais (ONGs), erigidas no alerta preventivo sobre as consequências morais do novo conhecimento e a salvaguarda da ordem vigente e dos direitos individuais. "Ironicamente - como nos adverte o mencionado autor - nos Estados Unidos da America, nos anos 80, no início da aceleração dos trabalhos e resultados da nova ciência e sua biotecnologia, o presidente Reagan aboliu a Comissão Presidencial para o Estudo dos Problemas Éticos na Medicina e na Pesquisa Biomédica e Comportamental.” (p.26)

As reflexões que esta última questão abre, nos levam a perguntar sobre qual o verdadeiro eixo do debate. Será que efetivamente se desenvolve entre "moral" e sociedade versus ciência e tecnologia? Ou em realidade seus avanços respondem e são o efeito de ideais sociais e históricos e refletem as particularidades da moral na sua contemporaneidade, e as contradições próprias a cada tempo histórico?

É comum ver situar esse debate como um "duelo" entre partes opositoras que por vezes tangenciaram um certo maniqueísmo que nos apresenta a ciência e suas descobertas ao modo de um "gênio maligno" do qual a Justiça e o Direito deveriam proteger os indivíduos e a sociedade tal como super-heróis, perante as perigosas invenções de um Lex Luthor materializado e real. Nossa intenção é tentar apontar, desde nossa perspectiva, de que modo esses acontecimentos científicos se inscrevem nos determinantes históricos, sociais e subjetivos do nosso tempo. Assim, este trabalho não visa nem insistir 
sobre a já tão batida listagem dos perigos e das consequências das novas descobertas e os seus possíveis abusos e nem mesmo aprofundar sobre as implicações das suas aparentemente ilimitadas possibilidades.

Toda descoberta científica substancial, no que diz respeito à mudança dos eixos preconcebidos, assim como todo grande acesso tecnológico, produz transformações radicais na moral vigente, mudanças na cosmovisão existente e na condição axiológica. Cada vez mais os valores dominantes verificam-se como temporais, contrariamente ao que desejaríamos que fossem: substanciais essenciais e eternos. A revolução copernicana e seus desdobramentos não se limitaram apenas a mudar a concepção existente do universo, dos astros e da Terra no seu conjunto. Sabemos que ela mudou radicalmente de lugar o eixo da terra e do homem.

Os guardiões da moral de então deveriam ao menos intuir o descentramento radical dos valores vigentes que esse conhecimento iria implicar. Se o homem não mais era filho único e axial de Deus, obrigado então a adorá-lo e servi-lo como contrapartida, o mundo como concebido desabaria. Não só o eixo do universo e do sistema planetário descentra-se como Copérnico. Deus foi também aí descentrado e letã e paulatinamente o homem foi fazendo passar por si e pela ciência o lugar de Deus. Se Deus era a resposta para o inefável e o desconhecido, o inefável deixou de ser esse resto que ficara fora do domínio humano e no lugar do divino, para passar a ser apenas o provisoriamente não conhecido. Ainda que esse processo aí aberto sofresse uma gradual porém insistente progressão até mostrar-se na sua onipotência atual.

Aquele descentramento geraria um Descartes (qualquer que fosse seu nome) e, com ele, o surgimento da ciência moderna e o advento do sujeito. Sujeito impensável antes dele, e mais ainda, esse sujeito cartesiano dividido entre um "penso" e um "sou". Sujeito este que mais tarde possibilitaria também a emergência de um Sigmund Freud, sua psicanálise e o seu sujeito radicalmente cindido entre "conhecimento" (campo do eu) e a verdade (campo do inconsciente) ${ }^{2}$. Sabemos muito bem, também, das preocupações e resistências do seu tempo às consequências morais que suas teses provocariam. Mas, do descentramento produzido pela revolução freudiana, nos interessa destacar uma consequência que vai na contramão do intercurso vigente. $\mathrm{O}$ indivíduo, emergindo na

2 Jacques Lacan, psicanalista francês cujo nome ficou associado ao de Freud na teoria Freud-lacaniana retoma o cogito cartesiano para pensar desde aí o inconsciente freudiano e a sua subversão. "Penso onde não sou e sou onde não penso" - Situado nesse "penso" o Inconsciente no deu deslizamento permanente, lugar do nãorealizado, e, no Sou, lugar do sentido, de consistência, de alienações nos ideais e nas imagos - Lugar do EU Onticamente então, o Inconsciente como o não realizado, seria o evasivo, o que escapa à certeza. "Isso pensa (manifestação do sujeito do inconsciente) antes de que entre na certeza" (momento do ser) - Se este movimento está condenado à repetição é porque o Real, como esse resto não realizado "retorna sempre ao mesmo lugar" - a esse lugar em que o sujeito em tanto que cogita, res cogitans, não o encontra". Ref. LACAN, Jacques. Los cuatro conceptos fundamentales del psicoanalisis. Seminário XI. Espanha: Barral Ed. 1977 
passagem da Idade Média tardia à Renascença, sofrerá com Freud o golpe desnarcisificante de ter de novo que aceitar que o seu Eu, que vinha sendo elevado a um palco cada vez maior, não era amo e senhor de si mesmo e dos seus atos, senão apenas escravo de outros poderes, desconhecidos a ele, que o determinavam e o condicionavam. Nossa contemporaneidade retoma, creio, o velho curso iniciado a partir dos desdobramentos inesperados do achado copernicano, sem dúvida alheio às intenções de Copérnioco: o início da progressiva destruição de Deus e o seu poder de Criador e a progressiva entronização do Ego Sapiens, no seu lugar.

Nossa contemporaneidade retoma aquele curso sentido de enunciar, ainda que de modo velado e nas entrelinhas, "a moral da história". A moral daquela história iniciada no advento da Ciência, agora com $\underline{\mathbf{C}}$ maiúsculo.

A Ciência no lugar de Deus pode criar o homem e o mundo, cloná-lo, vale dizer, gerá-lo não apenas "à imagem e semelhança" senão idêntico a si mesmo ou, ainda, destruir o mundo num novo "dilúvio", o atômico. Criar o homem e aperfeiçoá-lo.

No dia 27 de junho de 2000, dia em que "o DNA revelou os segredos do corpo humano" - como noticiaram os jornais, James Watson - prêmio Nobel e autor da concepção inicial, quando em 1953, na Universidade de Cambridge, descobriu, junto com Francis Crick, a estrutura de dupla hélice do ADN, mensageiro molecular da herança humana - disse: "Agora temos o livro de instrução da vida humana e teremos livros de instruções de várias outras formas de vida"3. Nesse mesmo dia e para o mesmo jornal, John Sulston, diretor do Sanger Center, centro britânico que participou do consórcio público responsável pela descobertas, manifestou: “chegamos a um ponto na história humana em que pela primeira vez, poderemos ter nas mãos o conjunto de instruções para se fazer um ser humano (sic!). Esse é um incrível passo filosófico e mudará, acho, a maneira como vemos a nós mesmos"4.

Destacaremos apenas um aspecto desse "incrível passo filosófico". Entendemos que nas diferentes aproximações que o homem tentou na sua procura ontológica, algo que é da ordem da estrutura psíquica e das relações do ser com as forças do desconhecido, se reitera nas religiões, nos mitos e nas diferentes teorias sobre o homem; algo da ordem de uma falta originária - falta no seu duplo sentido de incompletude originária, por um lado, e de culpa, por outro - por exemplo, a dívida simbólica na lógica psicanalítica e a culpa originariam na tradição judaico-cristã. Assim é que o homem carrega e é originado por uma falta que o determina, da qual não é autor, mas pela qual tem que se responsabilizar. Determo-nos na sua lógica não parece ocioso. No Gêneses, a falta originária se funda primeiramente num interdito originário que o primeiro homem

\footnotetext{
3 A biologia agora passa a ser ciência exata. Folha de S. Paulo 27 Jun. 2000. Caderno Ciência. A17.

4 Idem.
} 
transgride. Disse a serpente ao homem e à mulher "Deus sabe que no dia em que dele comerdes (referindo-se a árvore no meio do jardim) abrir-se-vos-ão os olhos e sereis como os deuses que conhecem o bem e o mal". (A BÍBLIA, v.I, p.13) Não se trata aqui nem da racionalidade e nem do discernimento moral que Deus não pode recusar a sua criatura nacional, esclarece o exegeta bíblico, senão da faculdade de decidir por si mesmo o que é bem e o que $\mathrm{PE}$ mal "O demônio sugere aos nossos progenitores uma grande conquista: series como os deuses, isto é, sereis autônomos, conhecedores do bem e do mal, a saber, a capacidade de decidir sobre o que é bem e o que é mal e de agir em conformidade com tal decisão". (p.13-14) Reivindicação de autonomia moral pela qual o homem nega seu estado de criatura. Falta originária pela qual a própria falta e a morte atingirão a todos os homens e que, na perspectiva do Novo Testamento, poderá reparar-se por um novo ato espiritual consistente na comunhão em Cristo.

Se, apenas como exemplos isolados, o retomamos na lógica da mitologia grega, Édipo nos apresenta uma mostra acabada desta concepção. Édipo é apenas um homem, frágil diante da impiedade divina, ou desse Outro incoercível. Mesmo possuindo consciência, lucidez e autodeterminação, representa o cotidiano fragmentário e impotente do homem, frente a forças que lhe são superiores. Sua saga expressa a concepção dos antigos gregos para os quais a culpa era como uma doença que se adquire sem o concurso da vontade individual. Vitima da maldição dos Labdacidas por uma falta que o antecedia, sua inocência não basta para impedir as consequências. Alguns elementos fundamentais aqui também se reiteram. Primeiro: ao lutar pela justiça, pela paz e pelo bem-estar, é justamente pelo deciframento dos enigmas sobre o ser do homem que a ele acede ao leito do incesto, ou, poderíamos dizer, da ilusória completude. Terceiro: será por meio de um ato ético, o de Antígona, sua filha, que esse ciclo se fechará. ${ }^{5}$

Uma falta nos antecede e nos determina - sob forma de uma condenação ou de um destino e na evidência da nossa limitação originária para cobri-la e pela qual devemos nos responsabilizar.

Freud, no seio de uma nova tradição racionalista - positivista que reinava soberana no século XIX e início do XX -, teorizava uma perspectiva do homem que é insuportável aos homens. Sua visão de homem é a do ser dividido entre um Eu subordinado (escravo de três amos: o Isso, o Super-Eu e a Realidade) e forças ignotas inconscientes que o compelem e que, embora desconhecidas de si mesmo, lhe pertencem. Seu ego e sua consciência não são donos nem determinam seus atos e, no entanto, esse sujeito é responsável por eles. $\mathrm{O}$ desconhecimento pelo $\mathrm{Eu}$, das leis e determinações inconscientes

5 É importante a serviço da lógica que estamos tentando apresentar através destas metáforas, fazer notar que o ato ético em Antigona consiste em dipor-se a pagar, até com sua vida, pela sustentação de Leis - as dos Deuses - ou as de um Outro ao que estamos submetidos enquanto falantes, superiores às leis normativizantes da polis ou dos homens - governantes. 
que condicionam sua conduta, e ainda seus sintomas, não o exime da responsabilidade por aquela. Mais ainda, assumir essa responsabilidade em ato, reconhecer que Isso fala nele e incluir na sua conta e no reconhecimento esse Outro que o habita, é condição necessária para a transformação ou cura.

Considerando que a ilusão da pesquisa genética é por vir a demonstrar a química e a "proteína" responsáveis não apenas pelos nossos traços genotípicos, somáticos, mas também pelos nossos afetos, emoções, sensações e condutas, assim como pelos nossos estilos característicos e modos relacionais, que vão desde nossas preferências gustativas até nossas escolhas sexuais, o homem que daí se deduz merece ser denotado.

Nosso tempo assiste a uma reviravolta fundamental a respeito da tradição conceitual a que fazíamos referência. O ser do homem a Ciência biomolecular nos "revela" (sic) é um homem que não é responsável, pois seu defeito/falta não é simbólico porém físico-molecular e seus atos seriam produto de uma genética responsável. Mas - e nota-se a importância disto - agora ele pode, graças à biotecnologia, mudar o seu destino, transformar sua determinação e manipular sua descendência, mediante uma intervenção instrumental. Mais ainda, longe de ter que responder por uma filiação, no que o Projeto Genoma promete a possibilidade de alterar nossa herança, seria possível desalinhavar-nos da cadeia. Alterar nossa filiação.

Nesse sentido nos perguntávamos se, nessa retomada do intercurso da ciência a que assistimos nesse século, da Ciência, trata-se de uma falência moral ou da chegada (suposta) a um ponto de estofo caracterizável como a moral da história. Assistimos a uma crise moral ou a um verdadeiro paroxismo, um acabamento paradigmático de moral em curso? Nessa perspectiva abordaremos mais adiante o que denominamos uma nova paixão do Ser.

\section{DA ESTRUTURA AOS IDEAIS - GENÉTICA E CONTEMPORANEIDADE}

Sistematicamente o homem produz mitos cuja função é dar conta ou explicar os grandes enigmas que o acossam. Fazê-lo, como veremos, é uma necessidade de estrutura. O homem produz mitos e é de certo modo produzido, orientado e se consiste neles. Eles operam como estruturas - estruturantes - estruturando-se.

O homem produz mitos tanto no nível individual quando no coletivo. No nível individual, e desde a óptica psicanalítica, a partir de perguntas como: "o que é um pai"? $\mathrm{O}$ que levará cada sujeito a construir um pai ideal. Isto, enquanto postulamos que um pai é eminentemente um significante no dizer da mãe, eminentemente simbólico por ser preponderantemente incerto. Isso, claro, até o advento dos exames de verificações de $\mathrm{ADN}$, que tornam os pais mais espermatozoicos ou genéticos, mas, nem por isso, mais efetivos. Mitos como resposta a este enigma, entre outros, tais como? "O que é e de onde vem essa sexualidade que o acossa e o possui", "Como compreendê-la em função 
de uma outra, ideal, suposta à normalidade e ao feliz desempenho e gozo, supostamente desfrutável pelos seus semelhantes", "O que quer uma mulher", "Qual é a origem das crianças". Nota-se o extenso repertório de mitos que circulam de pais para filhos sobre a questão em causa, assim como o rol de teorias infantis sobre a gestação e o nascimento que as crianças se colocam, até bastante tardiamente, para poderem vir a compreender e aceitar o coito parental como sua causa. ${ }^{6}$ É sabido que existem culturas - entre elas a dos Trobriandeses, na Polinésia - que não reconhecem a relação causal existente entre o coito e a gestação, pressupondo a gravidez gerada pela concepção do espírito de algum elemento da natureza valorizado cultural ou pessoalmente. De fato, isso implicará mudanças culturais na ordem da filiação e da linhagem, sendo a dos trobiandeses obviamente matrilinear e cabendo ao irmão da mãe a função paterna. ${ }^{7}$

Como se pode perceber, o poder do imaginário produz linhas de força que constroem o mundo e as relações entre os homens, muito além ou aquém das determinações ou limitações da biologia ou da realidade dos seus corpos. Nesse sentido, e começando a cernir nosso objetivo, o desenvolvimento das ciências biomédicas ao longo do século XX e mui especialmente o advento das tecnologias de transplante e de órgãos, assim como as técnicas de procriação assistida, evidenciaram a dissociação existente entre o corpo e o sujeito pensado como unidade indivisa (individuo). A ideia de indivíduo aliás, longe de ser eterna, é apenas pré-moderna e corresponde a um corpo radicalmente outro que o da pós-modernidade. Este, assim como o seu modo de inserirse no social, é sempre algo que tem a ver com o modo de inserção na subjetividade dominante. Tema que desenvolveremos adiante.

Retomando nossas argumentações sobre os enigmas que interrogam ao homem e que os mitos tentam responder: o que define exatamente no campo da identidade sexual o que seja do masculino ou do feminino para além dos genitais - que não dão conta da resposta - ou dos emblemas conjunturais que mudam de tempo em tempo?

6 Vide FREUD, Sigmund. Teorias Sexuais Infantis. 1908 Ed. Biblioteca Nova Madrid Espanha v. 1, ou ainda do mesmo autor, A Organização Genital infantil 1923 v. 2, entre vários e diferentes trabalhos sobre este conceito fundamental da teoria psicanalítica. A psicanálise sustenta que não existe inscrição inconsciente da diferença sexual anatômica, questão esta que se inscreverá apenas ao nível das instâncias do Eu constituindo a base das diversas problemáticas e diferentes comportamentos sexuais no campo da dita normalidade/neurose, assim como em outras afeções e psicopatologias.

7 A clínica nos oferece incontáveis exemplos e situações que testemunham não apenas da falta de um saber natural ou inscrito sobre esta questão, mas também uma curiosidade investigativa que nada quer saber, o repugna do descoberto, ao modo de uma recusa do conhecimento uma vez adquirido. Ainda note-se que este "conhecimento" é diferente de uma inscrição inconsciente de um saber. É praticamente regular escutar nos nossos consultórios afirmações do tipo: "meus pais nunca tiveram relações sexuais", "não tinha noção de vagina, não imaginava como algo poderia entrar ai, e, mais ainda, que minha mãe tivesse feito isso e eu tivesse vindo daí"! "Não gosto que venham contar... a gente sente uma coisa feia quando contam." "Minha mãe conta que a gente tinha nascido porque ela tinha rezado muito para que nós viéssemos. Com dez anos um primo me contou. Essa noite chorei muito. Minha mãe era uma vagabunda e tinha mentido". 
Afinal, os cromossomos pareceriam não determiná-la (eles xx, - xy, se parecem mais com um enigma da equação do que um fator determinante) e a anatomia, com seus condicionantes, tampouco é suficiente sequer para sustentar essa identidade ou para delimitá-la. Nós, psicanalistas, sabemos - pois a evidência clínica e o dizer de nossos analisantes nos ensinam - que a sexualidade humana constitui um leque de uma amplitude tal que se quiséssemos concebê-la como geneticamente determinada, deveríamos pressupor mutações na geração de cada indivíduo da espécie - malgrado não cessem de aparecer manuais, inclusão nos currículos primários e secundários de ensino, assim como sexologistas e professores prontos a ensiná-la o tempo todo, o homem continua a mitificá-la como natural e "normal" e supor-se a si mesmo como doente ou aberrante.

É fundamental à estrutura, antes de tudo, resguardar e salvar, manter ou produzir e preservar - por mais paradoxal que apareça a listagem - o ideal e a imagem da norma, com a ordem que ela implica.

Como vínhamos dizendo, imaginamos sistemas, produzimos mitos com o objetivo de explicar os enigmas que nos acossam em nível individual e em nível coletivo. Mitos sobre a origem do Universo, sobre a origem das espécies e do homem, mitos sobre as causas de todas e de cada uma das coisas, mitos sobre as razões dos nossos afetos, emoções e paixões e até sobre a lógica das nossas razões. E por esses mitos tomam feições de ciências.

Sua pluralidade e sua extensão ao longo de toda a história da humanidade deixam claro para nós a falta de algo de um Saber natural do homem. A sua pouca naturalidade. A falta de algo que ao modo de um instinto ${ }^{8}$ como no mundo animal, o oriente nas suas relações. Isso constitui o furo que articula os três registros - do imaginário, do Simbólico e do real - que o constituem, segundo a lógica do pensamento do teórico francês Jacques Lacan.

Tudo aquilo que o sujeito não consegue conhecer ou apreender do seu entorno e o angústia, tende a ser recoberto pelo imaginário. $\mathrm{O}$ imaginário tende a recobrir o real da sua falta de saber, de modo a consistir-se em uma ilusão que o oriente. $\mathrm{O}$ seu maior ou menor valor como verdade consiste expressar-se na extensão em que é compartilhado e universalizado entre os seus semelhantes, produzindo e organizando comunidades.

Muitos "conhecimentos" demonstraram ser apenas mitos bem estruturados. A estrutura destes mitos - independente da variedade das suas formas e conteúdos responde à própria lógica da estrutura psíquica e ao processo de estruturação do psiquismo, como mais adiante tentaremos fundamentar. Freud os apresenta como "ilusões

8 Por instinto entendemos um módulo de comportamento fixo e rígido para todos os indivíduos de uma mesma espécie. Inscrito como um "texto" opera como um decodificador dos sinais do entorno natural e dos seus semelhantes. Operando efetivamente como um saber natural sobre o habitat, as condições de autoconservação e conservação da espécie e os signos dos seus semelhantes orientam aos animais nas suas relações naturais. 
oriundas da obscura percepção interna que o sujeito tem de seu próprio aparelho psíquico". Projetadas para o exterior se expressariam em concepções de si e do mundo, da "imortalidade, da recompensa e todo o mais além". 9

Sucintamente diríamos que, ao contrário, a ciência visaria produzir um puro simbólico - equações e fórmulas matemáticas que não fizessem imagem alguma, com absoluta (se possível fosse) exclusão do sujeito -, visaria produzir também um efeito de conhecimento que não deixasse resto de enigma e que permitisse encontrar um dia " $a$ teoria de todas as coisas" - como o físico inglês Stephen Hawking chama a Teoria Quântica da Gravidade - e que explicaria a criação do universo. Isso malgrado insista em manifestar a provisoriedade das teorias científicas.

Na nossa concepção, alguns impossíveis fariam obstáculo a isso. $\mathrm{O}$ primeiro é o da ilusão de eliminar o sujeito da pesquisa. Muito debateu-se sobre isso e sabemos em que medida esse sujeito está presente e quanto o caminho da subjetividade dominante, em cada tempo histórico, deixa seu selo nas descobertas da vez, os interesses econômicos particulares e multinacionais, os valores morais, a vontade de prestígio e poder, enfim, as mil caras do narcisismo. Eis a estrutura e a estruturação do psiquismo humano fazendo aí também a sua obra.

O epistemólogo Thomas Kuhn (KUHN, 1993), na sua magistral obra sobre a astronomia planetária no desenvolvimento do pensamento ocidental, intitulada "A Revolução Copernicana", nos lembra que, ainda que as teorias astronômicas anteriores às que hoje reverenciamos sejam radicalmente diferentes das que aceitamos na atualidade, a maior parte das mesmas receberam na sua época uma adesão tão firme como a que hoje em dia adjudicamos às nossas. Além do mais, eram consideradas acertadas por indênticas razões, vale dizer, porque aportavam respostas plausíveis às questões que pareciam importantes. E ainda afirma, num critério que compartilhamos plenamente, que são muitas outras ciências que nos oferecem exemplos semelhantes no que diz respeito à transitoriedade das crenças científicas, mesmo que, de fato, os conceitos básicos da astronomia gozem ainda de uma estabilidade muito mais forte que os da maior parte das ciências.

Retomando, a segunda impossibilidade estrutural que, ao nosso entender, faria obstáculo ao já postulado ideal da ciência, é que na nossa concepção há sempre um resto que não se fecha e que se reabre constantemente a um novo enigma, pois entendemos que há uma disjunção estrutural entre Saber e Verdade, entre Saber Produzido e Verdade Toda suposta. A verdade, concebemos então como o que "corre atrás da verdade." (LACAN, 1974, p. 53) A história da ciência até a presente data, pelo menos, confirma esta asserção.

9 Carta a Filess. 
Assim, o real para nós diferentemente da realidade se constituiria da verdade dessa falta de saber sobre a Verdade e poderia ser definido como o que "o que retoma sempre ao mesmo lugar" (LACAN) ou, enquanto o resto não completado e indisponível, como "o que é expulso do campo da realidade pelo advento do simbólico". (LACAN) As ilusões mitificantes - que visam sempre reduzir a angústia do não sabido e o mal-estar estrutural próprio da humanidade e da civilização - preenchem o espaço deixado em aberto por esse resto insabido, mitificando e ampliando os limites da descoberta e suas possibilidades práticas de redução da dor e na promessa de um bem sem consequências. Mas o real, expulso pela porta, costuma retornar pela janela sob as formações mais imprevisíveis.

As maravilhosas perspectivas previstas com os avanços biotecnológicos que as recentes descobertas genéticas têm gerado, não escapam a esta lógica. $\mathrm{O}$ mal-estar, no entanto, se faz sentir na inquietação crescente, de amplos setores da sociedade, frente às consequências morais e à transformação radical da concepção e posição do ser humano, em relação aos valores tidos como fundamentais. Consequências e transformações estas imprevisíveis em função da aplicação prática desse novo saber adquirido. Isso, somado aos excessos ficcionais concomitantes a todo novo conhecimento emergente e ainda não provado nos seus efeitos, tanto os benéficos prometidos quanto os trágicos inesperados.

Nesses momentos de transição em que uma nova descoberta se oferece como possível de vir a mudar radicalmente o eixo no qual situávamos o ser na sua relação com o universo, o conjunto do sistema se comove. Os imaginários se agitam, a ciência-ficção antecipa futuras realidades e os seus caos e as instâncias jurídicas se apressam a tentar equacionar, em justo equilíbrio, as liberdades individuais e suas possíveis exações e violações no contexto do direito subjetivo, vale dizer, aqueles, nos limites de uma lei. Ou seja, limitar, não apenas os abusos possíveis decorrentes do poder econômico e os excessos do ilimitado desejo de poder atual da Ciência, mas também o inesgotável das demandas decorrentes da paixão que gera esse novo Saber sobre o Ser. Uma nova ideologia e novas demandas geram-se, ao redor dessa oferta.

Se introduzimos este capítulo expondo a questão dos mitos, não é porque nos interessa rebaixar a esse caráter, ou a um puro valor de doxa, certos conhecimentos científicos. É porque nos interessa pensar a forma em que estes serão apropriados pela estrutura e pelo registro do imaginário, produtor dessas ideologias.

Se, como Freud anunciou, certas descobertas científicas (teoria heliocêntrica; teoria evolucionista darwiniana, teoria psicanalítica do inconsciente) feriram o narcisismo da humanidade e a sua imagem de si (afirmações estas discutíveis como em certo sentido já apontei), uma questão se impõe: esta última e detonante descoberta da ciência , fere o narcisismo do homem? Ou ao contrário lhe oferece um novo acesso, o de posicionarse no lugar de Deus?

Uma das hipóteses mais grandiloquentes a partir do projeto Genoma - dirão alguns defensores - "é que o Projeto Genoma nos permitirá compreender no nível mais fundamental, o que é ser homem". (WILKIE, 1994, p.13) Isso é profundamente sugestivo. 
Essa busca de uma articulação entre Saber e Ser denota justamente um angustiante não saber sobre o Ser. Essa busca, sobre um fundo de não saber estrutural, movimenta todo nosso afazer e nossas descobertas e constitui, na nossa perspectiva, a própria essência do homem. Essência de sujeito dividido, como já dissemos, entre um Eu cognoscente em um Eu que denega a experiência vivida, base da repetição dos nossos erros e fracassos; cindido ainda mais entre uma consciência-razão e um inconsciente definível como o insabido que sabe e nos determina e governa e, ainda, escondido entre o Saber e a Verdade Toda, enquanto impossível ${ }^{10}$.

Mas essa falta essencial, essa incompletude que o caracteriza, torna-se a ele insuportável ainda que aparentemente pareça reconhecê-la ou aceitá-la. Seu discurso (o da Ciência) que insiste em reinterar "que nós chegaremos lá", que "impossível não existe", ou que "querer é poder", assim como as mais diversas tentativas de superar os limites que às vezes o conduzem à morte, têm também a sua expressão na procura científica. Por ela permite-se supor que os seus desconhecimentos são apenas provisórios e produto de uma limitação conjuntural e superável do poder dos instrumentos.

Assim, essa essência, ou "natureza" do seu ser, lhe escapa. Ela se evidencia em cada um dos seus movimentos, produções, períodos históricos, suas criações e suas mais geniais elucubrações, porém, sua essência lhe escapa. Porque lhe escapa, o homem sai sempre a perguntar-se por ela, numa nova repetição da procura da essência do ser. Sai a buscá-lo num território que lhe aparece cada vez mais cercável. No nosso tempo esse espaço é o território genético a ser explorado e mapeado para dar conta do ser. Que hoje se trate do Genoma como território, como lugar de escolha, segue a lógica de uma seriação histórica. Nele o ser e sua causa foram sendo procurados, supostos e situados do mais longínquo ao mais próximo, do exógeno ao endógeno, do transindividual e coletivo ao particular e subjetivo e, por último (avantar da contemporaneidade), do subjetivo, que inevitavelmente compreende o transindividual e o Outro, ao individual copóreo. Agora, então, campo mensurável, quantificável e computável. Logo, operacionalizável pelo computador, altar-mor das nossas devoções cotidianas.

Assim, a busca do ser passa de Deus ao Genoma, prévia passagem pela Natureza e o homem concebido como um elo desta.

Mas quais são as linhas de força dominantes nas buscas que exprimem a lógica dessa estrutura que resumidamente apresentamos?

Que se identifique o projeto Genoma Humano, como suposto momento cume do Saber sobre o Ser, com o dedo de Deus, nas representações imaginárias apresentadas

${ }^{10}$ Essa divisão fundamental decorre, na nossa teoria, do fato de o ser humano ser falante, dividido pela linguagem, condicionado por esta e estruturado (seu inconsciente) como uma linguagem e submetido a leis similares. Falando, ainda, desde muito antes de nascer pelo discurso do outro. Esta lógica requereria uma longa exposição mas excede as possibilidade desse ensaio. 
pelo marketing e os noticiários, não é casual. Não é casual, e nos lembra as primeiras buscas do homem no seu encantamento com a promessa da serpente: "vossos olhos se abrirão e sereis como os Deuses". (A BÍBLIA, v. I, p.13) Sua escolha teve um preço: a imortalidade. Perda esta, cujo valor o homem não podia estimar, desconhecedor que era do seu par significante opositor: a morte. ${ }^{11}$

No retorno em circuito do processo, o homem, no lugar de Deus, a partir do deciframento da escrita do código genético ("o livro da vidaI" [sic]) e sua manipulação instrumental, poderia vir, desde esse Saber sobre o Ser, a produzir um ser imortal. Não por acaso, justamente recuperar aquilo que teria perdido, a imortalidade, como consequência do accessus ao saber.

O P.G.H. (Projeto Genoma Humano), que torna acessível a intervenção e manipulação técnica do nosso patrimônio genético, abre nesse sentido perspectivas qualificadas de "espantosas" pelo físico brasileiro Luiz Alerto Oliveira (OLIVEIRA, 2000) considerando que, nas próximas décadas, ao projeto Genoma se sucederá o Projeto proteína, que permitirá, mediante a combinação de genes específicos, a produção de proteínas específicas e, em cadeia, células, tecidos e, num exercício de projeção possível, até indivíduos vivos completos "produzidos segundo design artificial, utilitário, antrópico". Assim, a imortalidade se perfila no horizonte como material e cientificamente possível. Quando exista essa capacidade de manipulação no nível molecular dos dispositivos de temporalização das células e telômeros, será, no seu dizer profético, possível produzir indivíduos literalmente perpétuos: "não será difícil prolongar indefinidamente a existência individual humana, malgrado as significações e consequências sociais dessa possibilidade". ${ }^{12}$

Para concluir esse apartado, queremos esclarecer que aqui, como ao longo do texto, a recorrência à questão bíblica é apenas uma menção metafórica, interessa-nos retomá-la como mito de fundação, criação e origem do ser que estrutura nossa tradição judaico-cristã.

De modo equivalente a qualquer outro mito ${ }^{13}$, ao tentar dizer sobre o indizível e o insabido do real da estrutura, põem-se em evidência os modos de funcionamento

${ }^{11}$ Somos afinal determinados pelo significante e sua lógica. Lógica na qual um significante sozinho não significa nada, precisando para se significar do seu par opositor. Ao menos dois, pois o substrato topológico do significante é a cadeia.

12 OLIVEIRA, Luiz Alberto. Ética para Centauros - Conferência apresentada na Plenária sobre o mal-estar na Pós-modernidade, no Seminário Internacional sobre Toxicomanias. Rio de Janeiro, 2000. Oliveira deduz dessa projeção uma transformação dos valores monstruosa, pois a sociedade poderá dividir-se em castas etárias segundo condições de durabilidade consistentes numa legião de Precários - sem condições mínimas de sobrevivência, uma minoria de Duráveis com acesso a bens essências e uma elite dominante de Perpétuos.

${ }^{13}$ Desde nossa perspectiva freud-lacaniana o texto do gênese pode ser considerado como equivalente aos outros mitos, mas não um mito como qualquer outro. Ele nos apresenta dois aspectos fundamentais e caros de nossa concepção do psiquismo: sua estruturação e a estruturação do sujeito. A criação ex-nihilo, por um lado, e a função a partir da Palavra. Ou seja, a Palavra como fundadora e estruturante. 
daquela, pois é justamente um de seus modos de produção. Isso evidentemente quando o mito é lido não de dentro das suas próprias determinações, mas desde Outro modo de olhar. Modo este que estamos tentando aplicar à leitura das produções teológicoreligiosas, aos mitos, às produções científicas e a alguns episódios históricos, como faremos mais adiante, para tentar extrair deles o que representam de estruturalmente equivalente no referente aos ideais do ser e suas expressões passionais extremas, por vezes na tentativa de consecução desse ideal e de sua relação com a moral.

\section{DE GEOMETRIAS IDEAIS AO IDEAL GENETECISTA}

A esfera constitui um modelo de estética e beleza transcendentais como única superfície perfeitamente simétrica. Organizada no supremo equilíbrio da sua total harmonia, na qual cada um dos pontos da sua superfície é igualitária equidistante de seu centro, possui um interior e um exterior notadamente separados, distintos, inconfundíveis e que não se interpenetram.

Para Platão, no seu Timeo a razão de que Deus tenha formado o mundo em forma esférica e circular teria sido para que fosse incorruptível, livre de doença e eterno.

Constitui um modelo ideal de perfeição enquanto "completamente semelhante a si mesmo" pois "Deus pensou que o semelhante é mil vezes mais belo"..., explica ainda o filósofo, no diálogo mencionado (PLATÃO. Timeo). Deus deve ser esférico.

O homem tem uma forte tendência a sonhar-se como uma esfera autocompletante ao modo do mito do andrógino de Aristófanes, no Banquete de Platão, constituindo uma imagem da completude procurada no ideal amoroso. A esses seres esféricos "é a eles que se refere, a tentativa de fazer uma escalada ao céu, para investir contra os deuses". (PLATÃO, 1972, p.29) $)^{14}$

Segundo Aristófanes, desde que foram retalhados por Zeus, os homens procuram desesperadamente voltar a locupletar-se. Possuem, não apenas no mito platônico, um ideal esferizado, ou se imaginam esféricos. No entanto, temos fortes motivos teóricos para postular que não o são. Sobrariam argumentos empíricos se recorrêssemos às misérias e incompletudes individuais decorrentes da natural limitação humana. Mas, contrariamente ao que poderia se supor, os homens, na sua intimidade, não justificam seus limites e impossibilidades num metro comum de "fraqueza" ou limitação espiritual

14 Nota do autor: É notória a insistência nos mitos e na religião de esse tema, manifestando um efetivo desejo inconsciente dos homens: chegar à morada dos deuses e usurpá-la, toná-los desnecessários realizando as funções supostas a eles, vencer a morte a que nos condenaram. A mitologia grega oferece inúmeros exemplos além do mencionado por Platão. Ícaro e sua tentativa de atingir os céus. Prometeu e seus veleidades de criador de homens, Sísifo e seu ato de aprisionar a morte e impedi-la, entre outros. Babel, na nossa tradição, retoma o tema. Os homens pressupõem também castigos implacáveis para essas tentativas, de parte dos deuses. Nossa contemporaneidade retoma o feito em todas suas expressões. Será que a deusa "consequência" também estará morta junto aos outros deuses? 
partilhada com a espécie. Trocam impossibilidade por impotência pessoal. Preferem salvar o ideal possível, o que encerra um contrassenso.

A clínica nos oferece testemunho disso. O que é da ordem da impossibilidade é vivido como "falha ou defeito" ou "culpa" pessoal, supondo aos outros uma harmonia essencial ou a possibilidade de alcançá-la. Distintamente desse ideal "esférico" ao qual deveria responder a espécie, postulamos uma outra topologia à estrutura humana, a Moebiana, diríamos sinteticamente.

Essa estrutura corresponde à de superfícies bem menos conhecidas que a esfera e cujas descrições ficam reservadas a tratados técnicos específicos de moderna matemática e geometria, mesmo que algumas delas datem da segunda metade do século XVIII ou decorram de um novo ramo da matemática definido em 1679 por Leibnitz como analysis situs. São superfícies da banda de Moebius, o Cross-cup e a Garrafa de Klein. Duas características as perpassam: são superfícies uniláteras, com indistinção de dentro-fora; interior e exterior se interpenetram e se confundem, não há senão uma aparência ilusória de delimitação e diferenciação entre esses dois supostos espaços, o espaço unilátero.

Elas reestruturam o espaço numa outra dimensão pouco conhecida. O conceito de profundidade cede lugar ao de percurso no tempo. É nos tempos deste percurso que um sujeito se supõe no "interior" ou no "exterior", numa topologia que alguma vez denominei in-exterior-ex-interior ${ }^{15}$. Baseados em Jacques Lacan, definimos dentro da lógica a relação de interpenetração delimitados e estanques, como o definem muitos.

Essa longa digressão - se bem que extremamente resumida dessa complexa questão - visa frisar dois aspectos. O primeiro, é insistir sobre o papel que nossos ideais têm na capacitação imaginária que temos do espaço do mundo e de nossa posição neles, considerando que é também desde esse registro que produzimos saberes científicos. $\mathrm{O}$ segundo, é oferecer uma perspectiva cuja lógica pode permitir entender como, em função de momentos pontuais do seu percurso, o homem se situou e localizou o seu ser tão diferentemente. Ora, como pura exterioridade a si próprio, numa totalidade holística, pressupondo a causa e razão do seu ser, de seus comportamento e de seu estar-no-mundo numa dimensão divina e a imagem e semelhança de um Deus absoluto. Ou ainda, como podemos ver no jovem Hegel, encantado no modelo da velha Grécia, anulando o indivíduo em proveito do todo, da força do absoluto, do império da totalidade. E, em outro momento pontual do percurso, seu posicionamento lhe faz situar no nível mais fundamental de seu ser de homem, na dimensão finita de seu interior, encerrado nos limites do código genético e reduzido a uma química molecular.

Tentar representá-lo como o faz o artista M. C. Escher - uma formiguinha circulando ao logo de uma banda de Moebius, que em si mesma presentifica o infinito

${ }^{15}$ Ver texto Norberto onde foi publicado ou apresentado. 
pode facilitar a visualização destas ilusões de percurso e possibilitar a compreensão de deus paradoxos.

Para produzir as superfícies anteriormente mencionadas e descritas - e para poder concebê-las ou representá-las mentalmente -, é necessário furar a esfera. Para concebê-las, foi necessário suportar furar os imaginários em que durante séculos nos sustentamos. "De fato - dirá Thomas Kuhn - existiram diversos universos de deus esferas, mas o importante para nós é que uma vez imposto tal esquema pode-se dizer que quase nunca se pôs em discussão sua veracidade. Durante quase dois milênios guiou a imaginação de todos os astrônomos e da maior parte dos filósofos". (KUHN, 1993, p.56)

Durante dois milênios, também, sacralizaram-se as teses sustentadas por Euclides no seu famoso "Elementos da Geometria", como verdades absolutas e definitivas, que aliás ainda nos acompanham, nas escolas, universidades e na nossa concepção de mundo e de espaço.

O espaço euclidiano e sua ideia de "profundidade" dominaram nossa óptica do mundo das ciências e determinaram consequências matemático-científicas e também suas limitações.

Ele responde bem à lógica do nosso imaginário: feitos à imagem e semelhança de Deus. Kant o definiu como um modelo de estética universal e pertencente à ordem das verdades inalteráveis.

Desmontar verdades dessa ordem tão isomórficas com o narcisismo próprio à estrutura humana, não é de fácil aceitação.

Copérnico, Darwin, Freud souberam desse funesto destino. Outra foi a sorte de Descartes. Ele colocou o sujeito no centro da cena. Não foram poucos os matemáticos que tentaram demonstrar a impropriedade de alguns dos postulados dos "Elementos"... sem se permitir no entanto, consegui-lo. Gauss, um deles, no início do século XIX, conseguiu, mas não suportou. Engavetou suas conclusões e o apelo de diversos matemáticos - entre eles Taurinus que chegou próximo de conseguir demonstrar a invalidade do quinto postulado - não foi suficiente para demovê-lo da sua negativa.

Talvez fosse fundamental preservar a ordem divina e sua estética transcendental: a euclidiana.

Quando finalmente um novo saber se impôs, um outro espaço veio à tona junto com as geometrias não euclidianas. ${ }^{16}$ Einstein foi possível graças a Riemann. Avanços

${ }^{16}$ Referimo-nos, por exemplo, à geometria hiperbólica do russo Nikolai Lobatchevski e também à do húngaro Janos Bolyai. O primeiro chegou a apresentá-la sem ser compreendido por ninguém - exceto Gauss que o sabia bem. A geometria elíptica de Riemann produziu um espaço n-dimensional, conhecido como o espaço riemanniano, sobre o qual Einstein pode construir a sua teoria da relatividade geral. Essa descrição não-euclidiana do espaço foi aplicada a ramos da Física, Microfísica, Óptica - a teoria do campo unificado, a teoria geral da propagação ondulatória, entre outras. 
estratosféricos - entre os quais se contam as viagens interplanetárias - se tornaram possíveis no campo de diversas ciências. A bomba atômica e a de hidrogênio, também.

A história da humanidade e a história das ciências comprovam que toda vez que o homem acedeu a um novo conhecimento colocou-o em prática até suas últimas consequências possíveis.

Desta vez, cremos, não será diferente a partir das perspectivas abertas pela pesquisa genética.

Reflexões de caráter éticos e as mais variadas especulações morais fazem hoje temer pelo fim do homem como o conhecemos: o homem-moderno. Aquela funesta consequência produzida a partir das técnicas de Einstein, fez o homem temer pelo fim da humanidade.

Torna-se interessante confrontar duas expressões paradoxais dessa experiência. Por um lado - na década de 1950 -, os governantes responsáveis escolheram pressuporse "escolhidos" por Deus para executar seus desígnios. ${ }^{17}$ Por outro lado, o homem e os filósofos sobre os riscos de se colocar no lugar de Deus.

Em verdade, o trágico desfecho da denotação da bomba atômica não destruiu o mundo, mas também não o deixou no mesmo pé. Toda uma transformação da ordem social e eminentemente uma nova moral, uma outra temporalidade e um outro modo de estar-no-mundo surgiram como mutações concomitantes aos efeitos da poeira atômica.

Essa conclusão pareceria evidente numa lógica binária de causa-efeito: as consequências possíveis do descontrole ético das pesquisas posteriores à descoberta einsteniana foram uma transformação radical do mundo a partir da segunda metade do século XX.

Vamos nos deter à analise do contexto moral dominante e das paixões que o precederam, para abrir outras perspectivas. Isso, no sentido de apontar que, no alvorecer do novo homem por vir, não se trata apenas de culpabilizar e tentar exorcizar o leque de transformações que a pesquisa genética propiciará, mas de pensar o decurso prévio da moral contemporânea e as demandas e exigências ideais que a propiciaram. Um breve percurso histórico à luz dos diferentes argumentos já desenvolvidos neste trabalho nos situará no eixo dessa reflexão.

17 O documentário "The Atomic Café" apresenta declarações à imprensa do secretário de defesa dos EUA e do presidente Eisenhauer extremamente interessantes nesse sentido: "descobrimos a bomba atômica e a usamos e iremos continuar a usá-la (sic!). É uma responsabilidade desagradável que nos foi dada. Agradecemos a Deus por tê-la enviado para nós (...) e rezamos para que Ele nos guie no caminho e para seus objetivos". Eisenhauer justificando os ensaios de Bikini com a bomba $\mathrm{H}$ : "Os Estados Unidos são a maior potência que deus já permitiu existir. Sendo assim, cabe a nós guiar este mundo a uma exitência pacífica e segura..." (sic!) 


\section{A MORAL E AS PAIXÕES DO SER}

Os derradeiros efeitos da modernidade deixavam sentir já, entrada a década de 1930, uma transformação radical da moral e dos valores vigentes. A ordem instituída do mundo e das relações sociais ameaçava ruir.

Hitler, expressão carnalizada e pessoalizada do percurso, cuja culminação foi a explosão atômica e suas consequências, parecia vê-lo assim: - uma "nova ordem" sob o modelo clássico de ordem - lida como a expressão da própria essência e substância da ordem - devia restaurar o mundo segundo seu modelo natural. ${ }^{18}$

Os desvios filosóficos, médico-clínico, políticos, artísticos e relacionais, deveriam se reordenar de modo a reencontrar a verdadeira natureza do homem e do mundo. $\mathrm{O}$ "nazismo alertava sobre um mundo prestes a ruir, que ameaçava mergulhar a Terra na escuridão eterna... Purificada e preservada de decadência, numa nova Alemanha (e o mundo já conquistado por ela) surgiria mais forte e mais bonita." 19

Se as diferentes expressões - entre elas a da arte moderna - dessa nova moral em cerne eram lidas como a expressão de uma degeneração da natureza do homem. Natureza posta como representada pelos modelos de saúde, força e beleza próprios ao classicismo greco-romano e renascentista; "naturalmente" os médicos e os artistas plásticos emergirão como líderes dessa transformação "que permitirá eliminar a doença".

Assim em 1933 dia 14 de julho - talvez como resposta à data comemorativa da revolução burguesa -, promulga-se a lei que obriga à esterilização dos doentes por causa da hereditariedade. E, dois anos mais tarde, em março de 1935, na Abertura da Exposição de Berlim que contava com um pavilhão exclusivamente destinado à medicina, como fundamentação da proposta de eugenia, Hitler manifestará que: "nosso primeiro princípio é de beleza e Saúde, os métodos da ciência vão assegurar isso... O médico já não está mais a serviço do indivíduo. Agora ele curo corpo da raça (ou dos melhores indivíduos da espécie possíveis de se obter com os métodos de então). Os médicos passam a ser peritos em estética. Problemas estéticos são problemas médicos. " ${ }^{\prime 20}$

Essa não é uma obra de ficção, mesmo que tenha tentado sustentar uma. E, então, qualquer semelhança com fatos ou particularidade da nossa realidade atual, seria de mera coincidência?

Duas questões nos interessam destacar deste longo parênteses. Por um lado, o sonho nazista de criar, através da pureza, um mundo mais harmonioso. Isto porque cremos que nas diferentes modalidades neomodernas em que se perfila um retorno

${ }^{18}$ Esclarecemos que essa leitura constitui a própria lógica do pensamento perverso. O perverso pressupõe a lei vigente e a ordem a ser transformada como transgressora em si mesma. Assim, no seu prisma, o seu ato é um ato restaurador da ordem e da lei natural. Ele não perverte a lei, a restitui no que supõe ser sua essência.

19 Referência não identificada entre os livros e testos de consulta do autor.

${ }^{20}$ Referência não identificada entre os livros e textos de consulta do autor. 
velado ao totalitarismo, os atuais ideais de pureza, perfeição, erradicação das doenças e um modelo de saúde concebido na lógica da hereditariedade genética e apoiado na ordem médica e o seu discurso do Todo-Saber, não deixam de provocar reminiscências e preocupações. Por outro, o que está posto na linha geral do nosso trabalho, que inclui as paixões do ser e o papel que nisto tem o estabelecimento de uma moral ou norma que possa situar-se no lugar de uma verdade absoluta, irrefutável e universal. Qualquer coisa capaz de colocar-se nesse lugar fascinará e cegará aos homens.

Em 1932, quase que premonitoriamente, Einstein, dentro de um programa do Institut de Coopération Internacionalle, interrogava Sigmundo Freud sobre o porquê da guerra e sobre "como é possível a essa pequena súcia dobrar a vontade da maioria que se resigna a perder e a sofrer com a má situação de guerra a serviço da ambição de poucos? ... e como esses mecanismos conseguem tão bem despertar nos homens um entusiasmo extremado, a ponto de estes sacrificarem suas vidas?" (EINSTEIN, p.241)

Hoje ante as promessas da biotecnologia, da genética e da engenharia genética faríamos uma pergunta similar: como é possível que os homens se fascinem frente à proposta genetecista? Uma proposta que, de ser verdadeira e vir a comprovar-se, reduziria o conjunto da existência humana e o seu ser a determinações puramente biológicas no nível mais elementar e rígido do código. Vale dizer, sob um conjunto de aspectos reduziria o seu livre arbítrio, o valor das suas escolhas e o peso da sua responsabilidade e liberdade. Deveríamos talvez concordar com Erich Fromm (FROMM, 1983) a respeito do "medo" e do "pesado fardo" da liberdade?

Tentaremos, no percurso, ir tecendo considerações sobre essa questão. Sobre a primeira pergunta diremos que as emergências que surgem como efeito das transformações temporais nos aparecem como desordem, sujeira, violência. Fazem parte de um estranho que, como angustiante, deve ser eliminado, excluído. Possuem um certo aspecto sinistro, pois situam fora de nós e na nossa frente, na nossa vizinhança, algo da ordem do íntimo e familiar, recalcado, desconhecido e inconsciente como aquilo de nós, insuportável a nós mesmo. Situemos alguns exemplos esclarecedores. A ofensiva contra a arte moderna que irá desencadear-se durante os primeiros anos do regime nacional Socialista tem um caráter higiênico. Segundo os artistas e as personalidades da cultura que faziam parte do comando partidário, os trabalhos dos artistas modernos mostram sinais da doença mental dos seus criadores. Concebida como arte degenerada, é comparada ponto a ponto com as expressões da perversão e da degeneração clínica. Suas representações são exageradas como a expressão do que pode ser encontrável nos sanatórios e manicômios.

De fato, no que essa arte passa a expor algo da ordem das paixões, e na ruptura com as formas convencionais, apresenta um Outro modo de olhar que põe em evidência algo d'Isso, campo das pulsões, do Inconsciente; expõe o que no fundo erradicamos, expulsamos, banimos de nossa consciência por obra do recalcamento e que, o diferente, o novo, o estrangeiro, e não o semelhante, faz retornar do recalcado. 
A sua equivalência com o encontrável nos sanatórios e manicômios é paradigmática, pois sabemos os lugares onde sempre se exerceu a violência de expurgar, de fora-cluir o que de nós, recalcado, emergia na realidade da loucura do semelhante, agora transformado em estranho.

Se o mundo é mutável, se os valores não são absolutos e eternos, então não há garantia para pôr em resguardo a angústia e a dor de existir.

Será que conceber a vida humana como a expressão de um programa genético, escrito na química do ácido desoxirribonucleico (ADN), oferece um texto confiável que garanta e explique nossa existência e os nossos atos, livrando-nos se não da dor, ao menos da responsabilidade e da culpa? Esta garantia é fascinante e encantadora!

Tom Wilkie, físico já citado e ex-presidente da Association os British Science Writers, nos lembra, e isso não é puro acaso, que o projeto Genoma "tem sido chamado o Santo Graal da biologia contemporânea" (WILKIE, 1994, p.11) Não é também por puro acaso que eu esteja traçando estas linhas sobre as ilusões da biotecnologia, em duplo plano ou em um plano de fundo com imagens de um cruzado da nossa modernidade, Hitler, que gostava de se comparar a um Robert Koch da política, que ao descobrir um micróbio (o bacilo de Koch) teria mudado a medicina.

Wilkie nos lembra também que "o Projeto Genoma - segundo afirmação de alguns dos seus defensores - nos permitirá compreender, no nível mais fundamental, o que é ser homem" (p.13) - vale dizer, nos dirá sobre a própria essência do SER.

Respondendo, com certo atraso a Einstein sobre o fascínio, diríamos, que Hitler irá tornar-se ponto de confluência e de identificações de todos os ideais de um povo, pois ele também tem uma resposta clara, absoluta e definitiva sobre o enigma do ser - e uma proposta de ordem moral verdadeira, uma nova ordem restaurada da antiga e eterna moral.

Ficou provado em diferentes tempo e processos históricos que, entre tantos outros, vão desde as cruzadas, as guerras religiosas e faxinas étnicas dos nossos dias, passando pelo mal radical da solução final hitleriana, que os homens podem pagar um alto preço pela identificação a esse ideal e por sentirem-se portadores desse traço diferencial. Sua proposta de construção de um homem novo, pondo a ciência e a medicina na frente desse processo, sua proposta de continuar as lutas de Pasteur e Koch, como dirá após invadir a Rússia e enviar os judeus para os campos de concentração e extermínio, e o fato de terem sido da sua inspiração as primeiras experiências de clonagem, agudizam nossas inquietações e nos interrogam sobre os novos preços a pagar. As disposições, cremos conhecê-las.

A escritora Cynthia Ozik dirá que "a solução final alemã era uma solução estética; era uma tarefa de preparar um texto, era o dedo do artista eliminando uma mancha; ela simplesmente aniquila o que era considerado não harmonioso". (OZICK, 1998, p.13) Era 
um arranjo de engenharia genética eliminando no campo dos entrecruzamentos possíveis as alternativas consideradas doentes, portadoras de feiura ou indesejadas. Ao modo de seleção de embriões pré-implantações ou de escolha das características genéticas dos doadores.

Afinal, nessas condições e nessa sociedade, os genes não precisariam esperar e trabalhar pelo melhor para seus filhos se pudessem calcular e operar de forma a obter os melhores filhos. Nesse sentido, do mesmo modo que vários indivíduos da nossa contemporaneidade, Hitler mostrou-se um pai amoroso e preocupado com os futuros filhos da raça. Às futuras gerações ofereceria um padrão de perfeição e beleza o mais "clonado" possível e à geração presente uma ordem estável, limpa verdadeira e definitiva.

A ordem "significa um meio regular e estável para nossos atos; um mundo em que as probabilidades dos acontecimentos não estejam distribuídas ao acaso, mas arrumadas numa hierarquia estrita - de modo que certos acontecimentos sejam altamente prováveis, outros menos prováveis, alguns virtualmente impossíveis", dirá Zygmunt Bauman (BAUMAN, 1998, p.15), reconhecido teórico da pós-modernidade. Supor que essa Ordem possa estar escrita no texto de um código genético é pressupor disponível ao alcance de nossas leituras o sonho do livro do Destino escrito nos astros, guardando em esferas esotéricas, imperfeitamente legível por videntes e cartomantes ou nas mãos e nos arbítrios do Bom Deus... nem sempre. E nas vicissitudes da pós-modernidade, boas cifras de dinheiro e o apego narcísico às pompas do descobridor podem fazer sempre um ótimo Deus de um bom cientista no sentido não só de ler, mas também de recompaginar os textos. Afinal, como o Prof. Robert Edwards, do centro de Politica e Ética Social da Universidade de Maschester, afirma "não se deve esperar dos cientistas orientação motal sobre as consequências de seu trabalho, pois os cientistas são notoriamente desprovidos de ética se comparados à população em geral". (EDWARDS, 1994, p.19)

Mas, cremos que esse modo particular de compreensão do limite ético e da própria ética faz parte da moral da nossa contemporaneidade ou, ressituando um eixo anterior de análise, os fatos que articulam o entretecido e a trama da nossa atualidade determinaram uma ordem, uma cosmovisão e uma posição dos sujeitos que constituem a nova moral dominante.

As próprias descobertas, antes ainda as buscas por esses viés e o tratamento dado ao campo oferecem a biotecnologia e a ciência genética, são fruto e expressão da moral dominante na pós-modernidade, se entretecem com ela, estão a ela condicionados e a condicionam.

A moral tem suas veleidades e é mutável, volúvel e tenta o tempo todo dar consistência às novas modalidades do ser e sustentar como verdade os sentidos conjunturais que o homem dá à vida e a sua existência. Mas, se dá consistência, também se arraiga, pois protege 
do real insuportável da falta de um sentido válido como universal, de uma causa consensualmente aceita e de uma finalidade ou teleologia genericamente partilhada.

A moral é uma das fases das paixões do ser, um dos avatares do ter que confrontarse com o insustentável do constante vir-a-ser. Um resseguro contra a também constante transformação do mundo e a mudança racial do eixo que propõe a cada cosmovisão temporal estabelecida.

Em suma, a moral é o conjunto de valores ideais que, na forma de emblemas, de um modo imaginariamente simbólico, tenta dar suporte e norte onde não há. Ficção falsamente considerada como real, hipostasia-se a uma bússola que nos faz acreditar na existência e vigência tradicional de um norte, como polo superior. A moral vela, assim, na injunção a segui-la como norma, as angústias do mal-estar estrutural próprio ao fato de que norma não há, como ordem natural, senão apenas como convenção normativizante a ser estabelecida, relativa e parcialmente seguida, transgredível e transformável.

Cada tempo tem os seus próprios mandamentos e suas próprias ilusões que, se bem modelam ritmos e compassos diferentes, pareceriam repetir uma mesma frase musical com variações: ou a identidade com Deus ou a identificação com Ele.

\section{REFERÊNCIAS}

A BIBLIA. O Pentateuco. Gênesis. São Paulo: Abril Cultural. Vol I

BAUMAN, Zigmund. O mal-estar da pós modernidade. Tradução Mauro Gama, Cláudia Martinelli Gama. Rio de Janeiro: Jorge Zahar Ed., 1998. p. 15

EDWARDS, Robert. Citado por WILKIE, Tom. Projeto Genoma - um conhecimento perigoso. Coleção Ciência e Cultura. Rio de Janeiro: Jorge Zahar Editor, 1994. p. 19

EINSTEIN, Por que a Guerra? Carta à Freud. Freud Sigmund Obras Completas. V. XXII. Rio de Janeiro: Imago Ed. p. 241.

FREUD, Sigmund. Teorias Sexuais Infantis - 1908 Ed. Biblioteca Nova Madrid Espanha v. 1, ou ainda do mesmo autor, A Organização Genital infantil 1923 v. 2.

FROMM, Erich. Medo a Liberdade. Rio de Janeiro: Jorge Zahar Ed., 1983.

KUHN, S. Thomas. La Revolución Copernicana. La astronomia planetária em el desarrollo del pensamiento occidental. Obras Mestras del Pensamiento Contemporâneo. Buenos Aires: Ed Planeta Argentina, 1993.

LACAN, Jacques. Los cuatro conceptos fundamentales del psicoanalisis. Seminário XI. Espanha: Barral Ed. 1977

LACAN, Jacques. Los cuatro conceptos fundamentales del psicoanalisis. Seminario XI. España: Barral Editores, S. A, 1974. p.53 (?)

OLIVEIRA, Luiz Alberto. Ética para Centauros - Conferência apresentada na Plenária sobre o malestar na Pós-modernidade, no Seminário Internacional sobre Toxicomanias. Rio de Janeiro, 2000. 
OZICK, Cynthia. Citada por BAUMAN, Zygmunt. O mal-estar da pós modernidade. Tradução Mauro Gama, Cláudia Martinelli Gama. Rio de Janeiro: Jorge Zahar Ed., 1998. p. 13

PLATÃO. Diálogos. O Banquete. Os Pensadores. Rio de Janeiro. Victor Civita Ed., 1972. p 29.

WILKIE, Tom. Projeto Genoma - um conhecimento perigoso. Trad. Maria Luiza Borges; revisão técnica Darci Fontoura de Almeida. Rio de Janeiro: Jorge Zahar Ed., 1994.

Recebido: março 2013

Aprovado: abril 2013 